Abstracta Iranicacta Iranica

Revue bibliographique pour le domaine irano-aryen

Volume 34-35-36 | 2017

Comptes rendus des publications de 2011-2013

\title{
Gocha R. Tsetskhladze (ed.). The Black Sea, Greece, Anatolia and Europe in the First Millennium BC
}

\section{Astrid Nunn}

\section{(2) OpenEdition}

1 Journals

\section{Édition électronique}

URL : http://journals.openedition.org/abstractairanica/41524

DOI : 10.4000/abstractairanica.41524

ISSN : 1961-960X

Éditeur :

CNRS (UMR 7528 Mondes iraniens et indiens), Éditions de l'IFRI

Référence électronique

Astrid Nunn, « Gocha R. Tsetskhladze (ed.). The Black Sea, Greece, Anatolia and Europe in the First Millennium BC », Abstracta Iranica [En ligne], Volume 34-35-36 | 2017, document 17, mis en ligne le 15 juillet 2016, consulté le 29 septembre 2020. URL : http://journals.openedition.org/abstractairanica/ 41524 ; DOI : https://doi.org/10.4000/abstractairanica.41524

Ce document a été généré automatiquement le 29 septembre 2020.

Tous droits réservés 


\title{
Gocha R. Tsetskhladze (ed.). The Black Sea, Greece, Anatolia and Europe in the First Millennium BC
}

\author{
Astrid Nunn
}

\section{RÉFÉRENCE}

Gocha R. Tsetskhladze (ed.). The Black Sea, Greece, Anatolia and Europe in the First Millennium BC. (= Mélanges Jan Bouzek). Leuven, 2011, 448 p. et nombr. ill. (Colloquia Antiqua, 1)

1 Jan Bouzek est un archéologue tchèque dont le centre d'intérêt est la Mer Noire du second mill. av. J.-C. jusqu'au Moyen Âge. Ainsi la période achéménide est bien présente dans le volume qui lui a été dédié pour son $75^{\text {ème }}$ anniversaire. La première contribution est de N. Theodossiev sur la Thrace du premier millénaire av. J.-C. (p. 1-60). L'A. rassemble les nombreux témoins écrits et archéologiques sur la période achéménide pour pouvoir résumer aussi bien l'urbanisation que l'architecture et les rituels mortuaires dans cette région. A. Avram s'intéresse à la tribu thrace des Gètes souvent mentionnés dans les sources classiques (p. 61-75). Hérodote est avec ses récits sur les Scythes également au centre du troisième article (J. G. F. Hind, p. 77-93). La contribution de l'éditeur Gocha R. Tsetskhladze porte également sur les Scythes ( $p$. 95-139) ainsi que le rapport sur le projet américano-ukrainien AUSKP (AmericanUkrainian Scythian Kurgan Project, N. T. Grummond e.a., p. 141-194). L'article de J. Boardman s'intitule "Persia in Europe" (p. 195-201) clôt la partie proprement achéménide. Ce volume est instructif et est de bon augure pour la nouvelle série Colloquia Antiqua pensée comme supplément à la revue Ancient West \& East. 


\section{AUTEURS}

\section{ASTRID NUNN}

Université de Munich 